\title{
ANALISA RISIKO K3 DENGAN PENDEKATAN HAZARD AND OPERABILITY STUDY (HAZOP)
}

\author{
Dini Retnowati ${ }^{1}$ \\ 1Teknik Industri, Fakultas Teknik \\ Universitas Maarif Hasyim Latif, Sidoarjo, Indonesia \\ e-mail : dini_retnowati@dosen.umaha.ac.id \\ Diterima: 25 Maret 2017. Disetujui : 20 Mei 2017. Dipublikasikan : 1 Juni 2017 \\ (C)2017 -TESJ Fakultas Teknik Universitas Maarif Hasyim Latif. Ini adalah artikel dengan \\ akses terbuka di bawah lisensi CC BY 4.0 (https://creativecommons.org/licenses/by/4.0/)
}

\begin{abstract}
ABSTRAK
CV. SS belum menerapkan manajemen K3 secara baik sehingga menyebabkan timbulnya beberapa kecelakaan kerja serta kesehatan para pekerja mengalami gangguan akibatnya proses produksi CV. SS menjadi terganggu. Sedangkan untuk memenangkan persaingan, CV.SS harus bisa mewujudkan kualitas layanan terbaik kepada customer di dalam produk-produknya, termasuk salah satunya aspek responsiveness atau kecepatan respon berkenaan dengan informasi dan produk itu sendiri. Di dalam penelitian ini, dilakukan analisis risiko kerja yang berakibat pada keselamatan dan kesehatan para karyawan di CV. SS, sehingga CV, SS dapat melakukan tindakan pengendalian dan pencegahan terhadap bahaya yang muncul. Dari pendekatan metode hazop diperoleh 5 sumber hazard yang muncul dimana sumber hazard conveyor bahan memiliki tingkat risiko paling tinggi sehingga mendapat prioritas terlebih dahulu untuk diperbaiki.
\end{abstract}

Kata kunci: hazop, k3, risk matriks, risiko

\section{PENDAHULUAN}

Potensi bahaya atau dapat disebut juga dengan hazard terdapat hampir di setiap lokasi dimana terdapat suatu aktivitas, baik di rumah, di kantor, di jalan, hingga di tempat kerja. jika hazard tersebut tidak teridentifikasi dengan tepat, tidak dikendalikan dengan baik akan dapat menyebabkan kelelahan yang kemudian menimbulkan cedera, dan bahkan kematian. Oleh karena itu, harus dilakukan pengendalian bahaya dengan menemukan dan mengidentifikasi adanya sumber hazard di tempat kerja. Temuan hazard tersebut kemudian diukur tingkat risikonya. Dari kegiatan tersebut dapat diupayakan suatu usaha pengendalian sampai pada tingkat aman bagi tenaga kerja, aset perusahaan dan lingkungan.

CV. SS merupakan suatu perusahaan pembuatan paving.CV. SS baru berdiri selama 2 tahun dimana dalam proses produksinya masih melibatkan beberapa proses manual dan belum menerapkan manajemen K3 secara baik. Hal ini menyebabkan timbulnya beberapa kecelakaan kerja serta kesehatan para pekerja mengalami gangguan. Sedangkan untuk memenangkan persaingan, CV. SS harus bisa memberikan pelayanan unggul dengan cara memberikan spesifisi kekuatan produk yang baik, pengiriman yang tepat waktu, memberikan harga yang bersaing dan memberi respon terhadap permintaan pelanggan dengan cepat dan tepat.
Berdasarkan latar belakang tersebut maka penelitian ini disusun dengan tujuan untuk melakukan analisis risiko terhadap keselamatan dan kesehatan kerja di CV. SS, sehingga CV, SS dapat melakukan tindakan pengendalian dan pencegahan terhadap bahaya yang berpotensi muncul di tempat kerja.

\section{METODE PENELITIAN}

Penelitian ini berkaitan dengan perbaikan penerapan program K3 di CV. SS dengan menggunakan pendekatan HAZOP untuk mengidentifikasi dan melakukan perancangan pengendalian terhadap potensi bahaya di tempat kerja. Teknik HAZOP dipilih karena HAZOP merupakan metode kualitatif yang mudah dipelajari, teliti, sistematis, logis, dan menuntut untuk memperoleh hasil yang teliti. Menurut (Asfahl \& Rieske, 2010), berikut ini adalah langkahlangkah yang dilakukan pada tahapan pengumpulan dan pengolahan data:

1. Dilakukan pemetaan urutan proses produksi

2. Dilakukan observasi lapangan guna melakukan identifikasi adanya potensi bahaya pada semua area kerja dengan mengamati adanya segala penyimpangan yang bisa bisa menjadi penyebab kecelakaan kerja .

3. Dilakukan pelengkapan kriteria pada HAZOP worksheet dengan urutan sebagai berikut: 
a. Pengklasifikasian potensi bahaya yang ditemukan (sumber potensi bahaya dan frekuensi temuan potensi bahaya).

b. Pendeskripsian penyimpangan selama proses operasi.

c. Pendeskripsian penyebab kejadian (cause).

d. Pendeskripsian akibat yang mungkin bisa timbulkarena penyimpangan tersebut (consequences).

e. Perumusan alternatif tindakan sementara.

f. Penilaian atas kemungkinan risiko (risk asessment) yang timbul dengan pendefinisian kriteria likelihood dan consequences/severity, seperti yang ditunjukkan pada Tabel 1 dan 2. Kriteria likelihood yang digunakan bersumber pada frekuensi kejadian di perusahaan dari tahun 2014 hingga tahun 2016. Kriteria consequences /severity yang digunakan didefinisikan sebagai akibat yang akan diterima pekerja jika terjadi kecelakaan kerja yang diintepretasikan secara kualitatif dengan selalu mempertimbangkan hari kerja yang hilang.

4. Dengan worksheet HAZOP dan memperhi- tungkan likelihood dan consequences, dilakukan identifikasi dan pemeringkatan potensi, lalu prioritas bagian mana yang didahulukan untuk dilakukan perbaikan bisa didapatkan dengan menggunakan risk matrix. Gambar 1 menunjukkan perhitungan nilai risk matrix.

5. Analisis dan pembahasan dilakukan dengan menjabarkan akar penyebab terjadinya kejadian kecelakaan kerja maupun gangguan proses kerja.

6. Perancangan perbaikan proses dilakukan pada stasiun atau area kerja yang teridentifikasi menimbulkan bahaya kecelakaan kerja pada CV. SS. Perbaikan proses dilakukan untuk mengurangi atau bahkan menghilangkan bahaya.

7. Kesimpulan dan Saran, untuk menemukan dan mensintesa jawaban dari semua permasalahan yang diangkat dalam penelitian ini.

\section{HASIL DAN PEMBAHASAN}

Potensi bahaya yang terjadi ketika proses produksi dapat diketahui dengan mengetahui alur

Tabel 1. Kriteria Likelihood

\begin{tabular}{|c|c|c|c|}
\hline \multicolumn{4}{|c|}{ Likelihood } \\
\hline \multirow{2}{*}{ Level } & \multirow{2}{*}{ Criteria } & \multicolumn{2}{|l|}{ Description } \\
\hline & & Kualitatif & Semi Kualitatif \\
\hline 1 & Jarang Terjadi & $\begin{array}{l}\text { Dapat dipikirkan tetapi tidak hanya saat } \\
\text { keadaan ekstrim }\end{array}$ & $\begin{array}{l}\text { Kurang dari } 1 \text { kali dalam } 10 \\
\text { tahun }\end{array}$ \\
\hline 2 & $\begin{array}{l}\text { Kemungkinan } \\
\text { Kecil }\end{array}$ & $\begin{array}{l}\text { Belum terjadi tetapi bisa muncul/terjadi } \\
\text { pada suatu waktu }\end{array}$ & Terjadi 1 kali per 10 tahun \\
\hline 3 & Mungkin & $\begin{array}{l}\text { Seharusnya terjadi dan mungkin telah } \\
\text { menjadi/muncul disini atau ditempat lain }\end{array}$ & $\begin{array}{l}1 \text { kali per } 5 \text { tahun sampai } 1 \\
\text { kali pertahun }\end{array}$ \\
\hline 4 & $\begin{array}{l}\text { Kemungkinan } \\
\text { Besar }\end{array}$ & $\begin{array}{l}\text { Dapat terjadi dengan mudah, mungkin } \\
\text { muncul dalam keadaan yang paling banyak } \\
\text { terjadi }\end{array}$ & $\begin{array}{l}\text { Lebih dari } 1 \text { kali per tahun } \\
\text { hingga } 1 \text { kali per bulan }\end{array}$ \\
\hline 5 & Hampir Pasti & $\begin{array}{l}\text { Sering terjadi, diharapkan muncul dalam } \\
\text { keadaan yang paling banyak terjadi }\end{array}$ & Lebih dari 1 kali per bulan \\
\hline
\end{tabular}

Tabel 2. Kriteria Consequences/Severity

\begin{tabular}{|c|c|c|c|}
\hline \multicolumn{4}{|c|}{ Consequences/Severity } \\
\hline \multirow[t]{2}{*}{ Level } & \multirow[t]{2}{*}{ Uraian } & \multicolumn{2}{|l|}{ Deskripsi } \\
\hline & & Keparahan Cidera & Hari Kerja \\
\hline 1 & $\begin{array}{l}\text { Tidak } \\
\text { Signifikan }\end{array}$ & $\begin{array}{l}\text { Kejadian tidak menimbulkan kerugian atau } \\
\text { cidera pada manusia }\end{array}$ & $\begin{array}{l}\text { Tidak menyebabkan } \\
\text { kehilangan hari kerja }\end{array}$ \\
\hline$\overline{2}$ & Kecil & $\begin{array}{l}\text { Menimbulkan cidera ringan, kerugian kecil } \\
\text { dan tidak menimbulkan dampak serius } \\
\text { terhadap kelangsungan bisnis }\end{array}$ & $\begin{array}{l}\text { Masih dapat bekerja pada } \\
\text { hari/shift yang sama }\end{array}$ \\
\hline 3 & Sedang & $\begin{array}{l}\text { Cedera berat dan dirawat dirumah sakit, tidak } \\
\text { menimbulkan cacat tetap, kerugian finansial } \\
\text { sedang }\end{array}$ & $\begin{array}{l}\text { Kehilangan hari kerja } \\
\text { dibawah } 3 \text { hari }\end{array}$ \\
\hline 4 & Berat & $\begin{array}{l}\text { Menimbulkan cidera parah dan cacat tetap } \\
\text { dan kerugian finansial besar serta } \\
\text { menimbulkan dampak serius terhadap } \\
\text { kelangsungan usaha }\end{array}$ & $\begin{array}{l}\text { Kehilangan hari kerja } 3 \text { hari } \\
\text { atau lebih }\end{array}$ \\
\hline 5 & Bencana & $\begin{array}{l}\text { Mengakibatkan korban meninggal dan } \\
\text { kerugian parah bahkan dapat menghentikan } \\
\text { kegiatan usaha selamanya }\end{array}$ & $\begin{array}{l}\text { Kehilangan hari kerja } \\
\text { selamanya }\end{array}$ \\
\hline
\end{tabular}

Sumber : Pujiono (2013) 
atau tahapan dari proses produksi di CV. SS Berikut ini merupakan alur proses produksi paving:

1. Proses pengayakan dan penakaran material: Pasir diayak untuk mendapatkan pasir yang halus serta kemudian dilakukan penakaran material untuk setiap batch produksi. Kedua proses ini dilakukan secara manual.
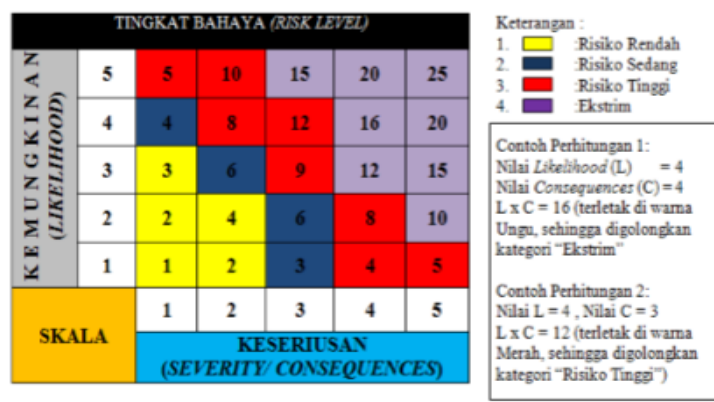

Gambar 1. Risk matrix

Sumber : Pujiono (2013)

2. Proses mixer: Sebelum proses pengadukan ini dilakukan, material yang berupa pasir, semen dan abu batu ditempatkan dulu ke dalam mesin pengaduk secara manual. Material tersebut kemudian diaduk hingga tercampur rata dengan mesin pengaduk. Setelah semua material adukan tercampur rata maka ditambahkan air dan dinyalana untuk diaduk kembali sehingga didapatkan adukan yang kebasahannya rata. Adukan/adonan agregat semen yang siap cetak dipindahkan ke mesin pencetak paving dengan menggunakan konveyor.

3. Proses pencetakan paving : Adonan paving yang berasal dari mesin adukan dipress/ditekan menggunakan mesin press hingga padat dan rata.

4. Proses curing : paving yang sudah jadi kemudian di pindahkan secara manual oleh 2 hingga 3 operator dengan menggunakan gerobak ke tempat curing. Proses curing disini menggunakan air, dimana produk paving ini harus dijaga untuk selalu tetap basah dengan menutup produk dengan plastik selama \pm 14 hari.

5. Proses pengeringan : Setelah melewati masa proses curing maka penutup plastik dibuka agar paving benar-benar kering.

6. Pengiriman : Pengiriman paving ke pelanggan dilakukan dengan menggunakan dump truck dan pick up. Proses pemindahan paving ke dalam truk dan pick up dilakukan secara manual.

Setelah itu dilakukan observasi di perusahaan secara langsung dan wawancara terhadap manajer operasi dan supervisor sebagai narasumber yang terpercaya untuk memperoleh temuan potensi bahaya (hazard). Tahapan selanjutnya adalah menentukan nilai likelihood (L), consequences (C) serta menentukan tingkat risiko untuk setiap sumber hazard yang muncul. Tabel 3 . menunjukkan hasil rekapitulasi dan pengolahan data menggunakan Hazop worksheet. Dari tabel Hazop worksheet diatas dapat diketahui bahwa ada 5 sumber hazard yang muncul yaitu mixer semen, conveyor bahan, mesin press sikap pekerja dan proses loading-unloading. Selanjutnya dilakukan perancangan rekomendasi atau usulan perbaikan yang disintesa berdasarkan hazard (potensi bahaya) yang bisa muncul atau terjadi. Rekomendasi atau usulan perbaikan diberikan terhadap seluruh sumber hazard yang muncul, namun untuk pelaksanaannya bisa diprioritaskan terlebih dahulu pada sumber hazard yang memiliki risikopaling tinggi. Dengan usulan perbaikan yang diberikan, diharapkan perusahaan dapat menurunkan atau bahkan menghilangkan tingkat kecelakaan dan bisal melakkan pencegahan adanya kecelakaan yang pernah terjadi sebelumnya. Tabel berikut merupakan analisis kejadian dari sumber bahaya dan sintesa usulan perbaikan berdasarkan level atau tingkat risikonya.

\section{PENUTUP}

Berdasarkan analisis dan sintesa yang telah dilakukan, terdapat 5 sumber bahaya kecelakaan kerja yang dapat terjadi diarea proses produksi paving. 5 sumber bahaya tersebut adalah conveyor bahan, sikap pekerja, proses loading dan unloading, mixer semen dan mesin press. Dari kelima sumber hazard tersebut, conveyor bahan memiliki tingkat risiko paling tinggi sehingga memperoleh prioritas untuk dilakukan perbaikan terlebih dahulu. Rancangan usulan perbaikan yang dapat dilakukan yaitu dengan pembuatan visual display yang berisi peringatan untuk tidak memasukkan tangan ke area conveyor bahan.

\section{DAFTAR PUSTAKA}

Asfahl, C. R., \& Rieske, D. W. (2010). Industrial safety and health management. Prentice Hall.

Pujiono, B. N., Tama, I. P., \& Efranto, R. Y. (2013). Analisis Potensi Bahaya Serta Rekomendasi Perbaikan Dengan Metode Hazard and Operability Study (HAZOP) Melalui Perangkingan OHS Risk Assessment and Control (Studi Kasus: Area PM-1 PT. Ekamas Fortuna). Jurnal Rekayasa Dan Manajemen Sistem Industri, 1(2), p253-263. 


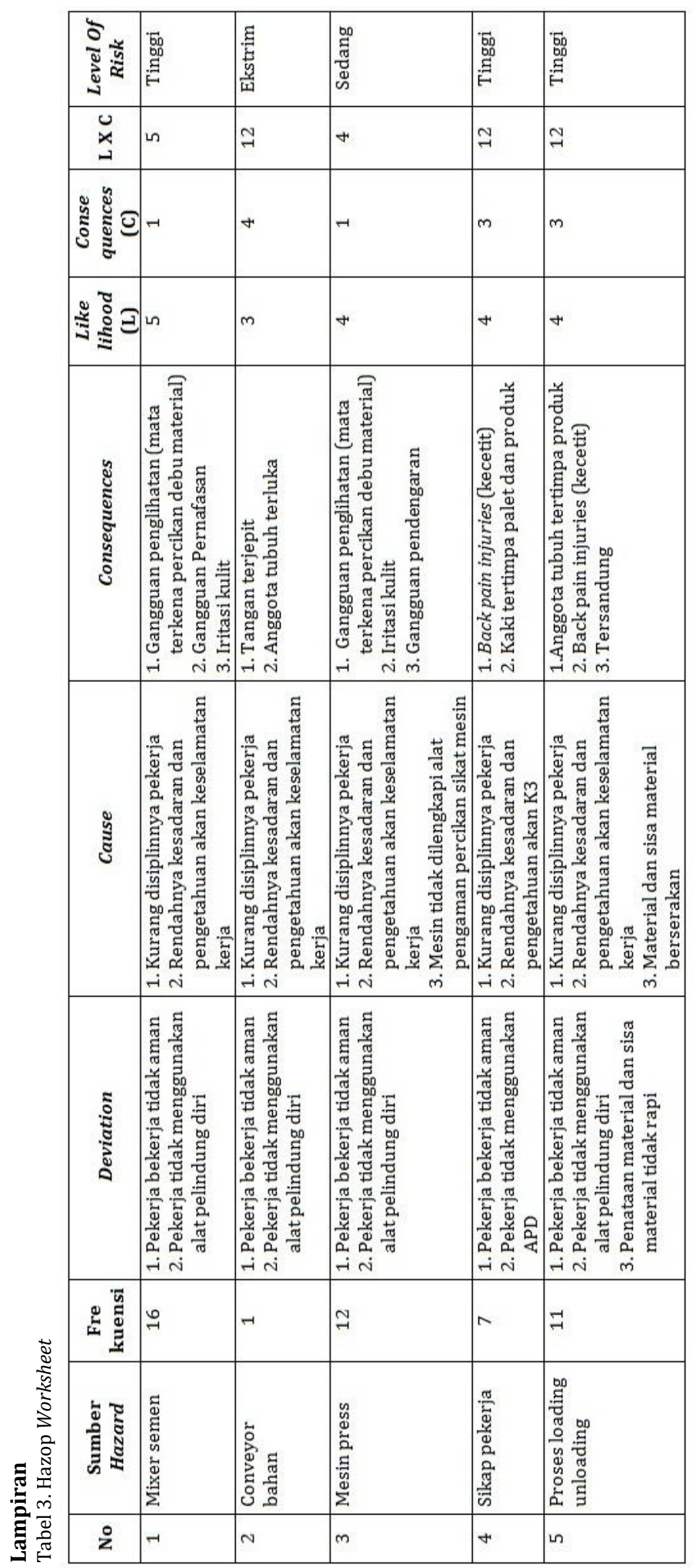


Tabel 4. Rekomendasi perbaikan

\begin{tabular}{|c|c|c|c|}
\hline No. & Sumber Hazard & $\begin{array}{l}\text { Level of } \\
\text { risk }\end{array}$ & Rekomendasi/usulan perbaikan \\
\hline 1 & Conveyor bahan & Ekstrim & $\begin{array}{l}\text { Membuat visual display yang berisi peringatan untuk } \\
\text { tidak memasukkan anggota tubuh ke bagian conveyor }\end{array}$ \\
\hline 2 & Sikap pekerja & Tinggi & $\begin{array}{l}\text { a. Membuat prosedur kerja yang baik } \\
\text { b. Memberikan pelatihan K3 pada para karyawan dan } \\
\text { memberikan sanksi bagi karyawan yang tidak } \\
\text { mengikuti pelatihan } \\
\text { c. Membuat visual display mengenai peringatan } \\
\text { penggunaan APD } \\
\text { d. Membuat lembar kontrol pelanggaran penggunaan } \\
\text { APD }\end{array}$ \\
\hline 3 & $\begin{array}{l}\text { Proses loading } \\
\text { dan unloading }\end{array}$ & Tinggi & $\begin{array}{l}\text { a. Membuat prosedur kerja yang baik } \\
\text { b. Memberikan pelatihan K3 pada para karyawan dan } \\
\text { memberikan sanksi bagi karyawan yang tidak } \\
\text { mengikuti pelatihan } \\
\text { c. Membuat visual display mengenai himbauan } \\
\text { penggunaan APD } \\
\text { d. Membuat lembar kontrol pelanggaran penggunaan } \\
\text { APD } \\
\text { e. Memperbanyak jumlah helm dan sepatu safety }\end{array}$ \\
\hline 4 & Mixer semen & Tinggi & $\begin{array}{l}\text { a. Membuat visual display mengenai peringatan } \\
\text { penggunaan APD } \\
\text { d. Membuat lembar kontrol pelanggaran penggunaan } \\
\text { APD } \\
\text { c. Memperbanyak jumlah masker dan menyediakan } \\
\text { kacamata safety }\end{array}$ \\
\hline 5 & Mesin press & Sedang & $\begin{array}{l}\text { a. Membuat pengaman berupa penutup depan mesin } \\
\text { untuk mengurangi percikan material } \\
\text { b. Menyediakan earplug } \\
\text { c. Memperbaiki tata letak penyimpanan material baru } \\
\text { dan memberikan tempat penampungan bagi material } \\
\text { sisa/rusak }\end{array}$ \\
\hline
\end{tabular}


D Retnowati / Teknika : Engineering and Sains Journal, Vol. 1, No.1, Juni 2017, 41-46

Halaman ini sengaja dikosongkan 